\title{
COMPETITIVE SORPTION AND DESORPTION OF PHOSPHATE AND CITRATE IN CLAYEY AND SANDY LOAM SOILS ${ }^{(1)}$
}

\author{
Matheus Fonseca de Souza ${ }^{(2)}$, Emanuelle Mercês Barros Soares ${ }^{(3)}$, Ivo Ribeiro da Silva ${ }^{(4)}$ \\ Roberto Ferreira Novais ${ }^{(5)}$ \& Mailson Félix de Oliveira Silva ${ }^{(6)}$
}

\begin{abstract}
SUMMARY
The increase of organic acids in soils can reduce phosphorus sorption. The objective of the study was to evaluate the competitive sorption of $P$ and citrate in clayey and sandy loam soils, using a stirred-flow system. Three experiments were performed with soil samples (0-20 cm layer) of clayey (RYL-cl) and sandy loam (RYL-sl) Red Yellow Latosols (Oxisols). In the first study, the treatments were arranged in a $2 \times 5$ factorial design, with two soil types and five combinations of phosphorus and citrate application (only $\mathrm{P} ; \mathrm{P}+$ citrate; and citrate applied 7, 22, 52 min before $\mathrm{P}$ ); in the second, the treatments were arranged in a $2 \times 2$ factorial design, corresponding to two soils and two forms of $P$ and citrate application (only citrate and citrate $+P$ ); and in the third study, the treatments in a $2 \times 2 \times 6$ factorial design consisted of two soils, two extractors (citrate and water) and six incubation times. In the RYL-cl and RYL-sl, $P$ sorption was highest (44 and $25 \%$ of $P$ application, respectively), in the absence of citrate application. Under citrate application, $P$ sorption was reduced in all treatments. The combined application of citrate and $P$ reduced $\mathrm{P}$ sorption to $25.8 \%$ of the initially applied $\mathrm{P}$ in RYL-cl and to $16.7 \%$ in RYL-sl, in comparison to $P$ without citrate. Citrate sorption in RYL-cl and RYL-sl was highest in the absence of $P$ application, corresponding to 32.0 and $30.2 \%$ of the citrate applied, respectively. With $P$ application, citrate sorption was reduced to 26.4 and $19.7 \%$ of the initially applied citrate in RYL-cl and RYL-sl, respectively. Phosphorus desorption was greater when citrate was used. Phosphorus desorption with citrate and water was higher in the beginning (until $24 \mathrm{~h}$ of incubation of $\mathrm{P}$ ) in RYL-cl and RYL-sl, indicating a rapid initial phase, followed by a slow release phase. This suggests that according to the contact time of $P$ with the soil colloids, the previously adsorbed $P$ can be released to the soil solution in the presence of
\end{abstract}

(1) Excerpt from the Master's thesis of the first author of the Post-Graduate course in Soil and Plant Nutrition at the Federal University of Viçosa - UFV. Received for publication on August 22, 2013 and approved on May 6, 2014.

${ }^{(2)}$ Initiator of Rural Development at the Capixaba Institute of Research Technical Assistance and Rural Extension - INCAPER Rua Desembargador Epaminondas do Amaral, 116, Centro. CEP 29390-000 Iúna (ES), Brazil. E-mail: matheus-ufes@hotmail.com

(3) Adjunct Professor, Soil Science Department - DPS, UFV. Av. P. H. Rolfs, s/n. CEP 36570-900 Viçosa (MG), Brazil. E-mail: emanuelle.soares@ufv.br

(4) Associate Professor, DPS, UFV. E-mail: ivosilva@ufv.br

(5) Full Professor, Sênior National Researcher/FAPEMIG, UFV. Campus Rio Paranaíba. Rod. MG 230, km 7. CEP 38810-000 Rio Paranaíba (MG), Brazil. E-mail: rfnovais@ufv.br

(6) Undergraduate student in Agronomy, PIBIC-CNPq Scholarship holder, DPS, UFV. E-mail: mailson.silva@ufv.br 
competing ligands such as citrate. In conclusion, a soil management with continuous input of organic acids is desirable, in view of their potential to compete for $\mathbf{P}$ sorption sites, especially in rather weathered soils.

Index terms: incubation time, Latosol, organic acids, stirred-flow.

\title{
RESUMO: SORÇÃO E DESSORÇÃO COMPETITIVA DE FÓSFORO E CITRATO EM SOLOS DE TEXTURA MUITO ARGILOSA E FRANCO-ARENOSA
}

\begin{abstract}
$O$ aumento de ácidos orgânicos pode induzir à redução da sorção de $P$ em solos. Este trabalho objetivou avaliar a sorção competitiva de $P$ e citrato em solos de textura muito argilosa e franco-arenosa, utilizando o sistema de fluxo contínuo (stirred-flow). Foram realizados três experimentos com amostras da camada de 0-20 cm de dois Latossolos VermelhoAmarelo, texturas muito argilosa (LVA_arg) e franco-arenosa (LVA_fa). No primeiro, os tratamentos foram definidos por fatorial $2 \times 5$, sendo dois solos e cinco configurações de aplicação de $P$ e citrato no solo (apenas $P, P+$ citrato e citrato 7, 22, 52 min antes do $P$ ); no segundo, os tratamentos foram determinados por fatorial $2 \times 2$, dois solos e duas formas de aplicação de Pe citrato no solo (apenas citrato, citrato $+P$ ); e, no terceiro, os tratamentos foram definidos segundo um fatorial $2 \times 2 \times 6$, sendo dois solos, dois extratores (citrato e água) e os seis periodos de incubação. Ovalor máximo da sorção de P no LVA_arg e LVA_fa foi observado na testemunha sem aplicação de citrato, correspondendo a 44 e $25 \%$ do $P$ aplicado, respectivamente. Com a aplicação de citrato, a sorção de $P$ foi inferior em todos os tratamentos. A aplicação de citrato junto com P reduziu a sorção do P aplicado para 25,8\% no LVA_arge $16,7 \%$ no LVA_fa, em relação à aplicação de $P$ sem citrato. $O$ valor máximo da sorção de citrato no LVA_arg e LVA_fa ocorreu no tratamento sem adição de P, correspondendo a 32,0 e $30,2 \%$ do citrato aplicado, respectivamente. Com aplicação de $P$, a sorção de citrato reduziu para 26,4 e 19,7\% do citrato aplicado no LVA_arg e LVA_fa, respectivamente. A dessorção de $P$ foi maior com a utilização do citrato. A dessorção com citrato e água foi inicialmente superior (até $24 \mathrm{~h}$ de incubação de P) no LVA_arg e LVA_fa, caracterizando uma fase inicialmente rápida, seguida de uma fase lenta, sugerindo que, dependendo do tempo de contato do $P$ com os coloides do solo, o P previamente sorvido pode ser liberado para a solução, se ligantes competitivos como o citrato estiverem presente. Assim, o manejo de solo que adiciona de forma continuada ácidos orgânicos, uma vez que esses apresentam o potencial de competir pelos sítios de sorção de $P$, seria almejado, principalmente em solos mais intemperizados.
\end{abstract}

Termos de indexação: ácidos orgânicos, Latossolo, incubação, stirred-flow.

\section{INTRODUCTION}

Most tropical soils have a high $\mathrm{P}$ sorption capacity, due to the predominance of $\mathrm{Fe}$ and $\mathrm{Al}$ oxyhydroxides in the clay fraction. The sorption reduces $\mathrm{P}$ availability to plants because the soil sink begins to dominate over the plant sink (Novais \& Smyth, 1999). Phosphorus sorption reactions are fast: Gonçalves et al. (1985) observed that about $75 \%$ of the $\mathrm{P}$ application was retained in less than half an hour of reaction in Oxisol samples.

The predominant interaction of $\mathrm{P}$ with $\mathrm{Fe}$ and $\mathrm{Al}$ oxyhydroxides determines the $\mathrm{P}$ lability and hence plant availability. Phosphorus in solution and weakly sorbed $\mathrm{P}$ are considered labile forms of soil $\mathrm{P}$ (labile $\mathrm{P})$. Desorption-resistant $\mathrm{P}$ with more stable connections characterizes non-labile forms. With increasing soil incubation time, the $\mathrm{P}$ availability is reduced, regardless of the soil type or applied $\mathrm{P}$ rate (Novais \& Smyth, 1999; Broggi et al., 2010; Hamdi et al., 2014).
The kinetics of soil $\mathrm{P}$ sorption and desorption are characterized by two phases: a first rapid, followed by a second slower phase (Shariatmadari et al., 2006; Harvey \& Rhue, 2008; Fekri et al., 2011; Wang et al., 2013). The sorption and desorption kinetics in soil are mainly controlled by the content of soil organic matter (SOM), clay content, $\mathrm{pH}$ and $\mathrm{Fe}$ and $\mathrm{Al}$ oxyhydroxides (Sharpley, 1983; Nafiu, 2009; Santos et al., 2011). With regard to clay, the number of $\mathrm{P}$ sorption sites is greater, when the clay content is higher, reducing P availability (Novais \& Smyth, 1999).

Phosphorus sorption in the soil was reduced in the presence of organic acids (Andrade et al., 2003; Souza et al., 2006; Duputel et al., 2013). Organic acids can be retained in the soil with high energy and block $\mathrm{P}$ sorption sites (Haynes, 1984). The carboxylic groups, characteristic of these organic acids, can dissociate and release protons in a wide $\mathrm{pH}$ range and promote the dissolution of soil minerals (Andrade et al., 2003; Oburger et al., 2011a). A great effectiveness of citrate 
was noted in the competition for P sorption sites; this greater competitiveness is due to the higher number of carboxylic groups (tricarboxylic).

The competitive sorption between $\mathrm{P}$ and organic acids has been widely tested in closed systems, while in this study, this assessment is proposed with a continuous flow system, by the stirred flow technique. In this system, reactions are relatively fast and the sorption and desorption kinetics can be measured in a single experiment (Sparks et al., 1996; Yin et al., 1997). This technique has been used for many years in several countries to investigate sorption and desorption of metals (Carski \& Sparks, 1985; Bar-Tal et al., 1990; Strawn \& Sparks, 2000), and also of P, although in fewer studies (Staats et al., 2004; PérezNovo et al., 2011).

As the $\mathrm{P}$ bindings with the solid phase of very weathered soils are highly stable and the reversibility low, one possibility of soil management would be the continuous addition of organic acids. This would lead to a competitive sorption between $\mathrm{P}$ and organic acid, favoring the plant sink and reducing the conversion of labile into non-labile $\mathrm{P}$ forms. Thus, the objective of this study was to evaluate the competitive sorption of $\mathrm{P}$ and citrate in clayey and sandy-loam textured soils, and to assess the effect of citrate on $\mathrm{P}$ desorption during different incubation times of this nutrient in the soil by the stirred flow method.

\section{MATERIAL AND METHODS}

Soils samples were collected from the 0-20 cm layer of two Red-Yellow Latosols (RYL), one with a clayey texture (RYL-cl), in Viçosa, Minas Gerais, and the other a sandy loam texture (RYL-sl), in Três Marias, Minas Gerais. Physical and chemical soil properties are listed in table 1. Particle-size analysis was performed with the pipette method adapted by Ruiz (2005) and the $\mathrm{C}$ content determined by dichromate oxidation (Yeomans \& Bremner, 1988); the total soil $\mathrm{N}$ was determined by the Kjehdal method; available $\mathrm{P}$ and exchangeable $\mathrm{K}$ were extracted by Mehlich-1; $\mathrm{Ca}, \mathrm{Mg}$ and $\mathrm{Al}$ were extracted by $1 \mathrm{~mol} \mathrm{~L}^{-1} \mathrm{KCl}$ and the $\mathrm{pH}$ measured in water, at a ratio of $1: 2.5$. The $\mathrm{P}$ content was determined by colorimetry of the phosphomolybdic complex, as described by Braga \& Defelipo (1974); K was determined by flame photometry; $\mathrm{Ca}$ and $\mathrm{Mg}$ by atomic absorption; and $\mathrm{Al}$ by titration (Defelipo \& Ribeiro, 1981). The elements $\mathrm{Fe}, \mathrm{Cu}$ and $\mathrm{Mn}$ were extracted by Mehlich-1 and determined by atomic absorption spectrophotometry. The remaining $\mathrm{P}$ (P-rem) was determined in the reaction solution after shaking the soil for $1 \mathrm{~h}$ with $\mathrm{CaCl}_{2}$ containing $60 \mathrm{mg} \mathrm{L}^{-1} \mathrm{P}$, at a ratio of 1:10 (Alvarez V. et al., 2000).

The maximum $\mathrm{P}$ sorption capacity (MPSC) of the soils was determined as proposed by Olsen \&
Table 1. Physical and chemical properties of a clayey texture Oxisol (RYL-cl) and sandy-loam texture Oxisol (RYL-sl)

\begin{tabular}{|c|c|c|}
\hline Property & RYL-cl & RYL-sl \\
\hline Coarse sand $\left(\mathrm{g} \mathrm{kg}^{-1}\right)$ & 140 & 225 \\
\hline Fine sand $\left(\mathrm{g} \mathrm{kg}^{-1}\right)$ & 190 & 535 \\
\hline Silt $\left(\mathrm{g} \mathrm{kg}^{-1}\right)$ & 60 & 50 \\
\hline Clay $\left(\mathrm{g} \mathrm{kg}^{-1}\right)$ & 610 & 190 \\
\hline $\mathrm{C}\left(\mathrm{g} \mathrm{kg}^{-1}\right)$ & 10.19 & 1.60 \\
\hline Total N $\left(\mathrm{g} \mathrm{kg}^{-1}\right)$ & 0.57 & 0.00 \\
\hline $\mathrm{pH}\left(\mathrm{H}_{2} \mathrm{O}\right)$ & 4.80 & 4.70 \\
\hline $\left.\mathrm{K}(\mathrm{mg} \mathrm{dm})^{3}\right)$ & 14.40 & 2.34 \\
\hline $\mathrm{P}\left(\mathrm{mg} \mathrm{dm}{ }^{-3}\right)$ & 1.31 & 0.03 \\
\hline P-rem $\left(\mathrm{mg} \mathrm{L}^{-1}\right)$ & 6.96 & 22.92 \\
\hline $\mathrm{Ca}^{2+}\left(\mathrm{cmol}_{\mathrm{c}} \mathrm{dm}^{-3}\right)$ & 0.55 & 0.10 \\
\hline $\mathrm{Mg}^{2+}\left(\mathrm{cmol}_{\mathrm{c}} \mathrm{dm}^{-3}\right)$ & 0.04 & 0.00 \\
\hline $\mathrm{Al}^{3+}\left(\mathrm{cmol}_{\mathrm{c}} \mathrm{dm}^{-3}\right)$ & 0.78 & 0.00 \\
\hline $\mathrm{Cu}\left(\mathrm{mg} \mathrm{dm}^{-3}\right)$ & 1.58 & 0.39 \\
\hline $\operatorname{Mn}\left(\mathrm{mg} \mathrm{dm}^{-3}\right)$ & 5.80 & 0.88 \\
\hline $\mathrm{Fe}\left(\mathrm{mg} \mathrm{dm} \mathrm{m}^{-3}\right)$ & 48.83 & 13.61 \\
\hline $\operatorname{MPSC}^{(1)}\left(\mathrm{mg} \mathrm{g}^{-1}\right)$ & 1.09 & 0.40 \\
\hline Equivalent moisture $\left(\mathrm{kg} \mathrm{kg}^{-1}\right)$ & 0.32 & 0.15 \\
\hline
\end{tabular}

$\mathrm{P}$ available and $\mathrm{K}$ exchangeable extracted by Mehlich-1 (Braga \& Defelipo, 1974); exchangeable $\mathrm{Ca}, \mathrm{Mg}$ and $\mathrm{Al}$ extracted by $\mathrm{KCl} 1 \mathrm{~mol} \mathrm{~L}^{-1}$, Al quantified by titration (Defelipo \& Ribeiro, 1981). Fe, $\mathrm{Cu}$ and $\mathrm{Mn}$ extracted by Mehlich-1. (1) MPSC: maximum $\mathrm{P}$ sorption capacity.

Watanabe (1957) and modified by Alvarez V. \& Fonseca (1990). The $\mathrm{P}$ concentrations to determine MPSC were calculated based on the P-rem content and each soil was treated with 11 soil $\mathrm{P}$ concentrations $\left(0,10,20,30,50,70,90,110,140,170\right.$, and $200 \mathrm{mg} \mathrm{L}^{-1}$ in RYL-cl, and $0,5,10,15,25,35,45,55,70,85$, $100 \mathrm{mg} \mathrm{L}^{-1}$ in RYL-sl) (Alvarez V. \& Fonseca, 1990). We used $2.5 \mathrm{~g}$ air-dried fine soil (ADFS) of each soil and added $25 \mathrm{~mL}$ of a $0.01 \mathrm{~mol} \mathrm{~L}^{-1} \mathrm{CaCl}_{2}$ solution containing the $\mathrm{P}$ concentrations. The solution was stirred for $24 \mathrm{~h}$ and centrifuged for $5 \mathrm{~min}$, to determine the $\mathrm{P}$ concentration in the supernatant. The MPSC was estimated by the linearized Langmuir isotherm (Equation 1):

$$
\frac{C}{q}=\frac{1}{a b}+\left(\frac{1}{b}\right) C
$$

where $C$ is the $\mathrm{P}$ concentration in the reaction solution, in $\mathrm{mg} \mathrm{L}^{-1} ; b$ is the MPSC of the soil, in $\mathrm{mg} \mathrm{g}^{-1} ; q$ is the amount of $\mathrm{P}$ sorbed in soil, in $\mathrm{mg} \mathrm{g}^{-1}$; and $a$ is a constant related to the binding energy of the element to the soil, in $\mathrm{L} \mathrm{mg}^{-1}$.

The sand, silt and clay mineralogy was analyzed. The clay and sand fractions were ground in a mortar and oriented on glass slides for mineral identification by X-ray diffraction. Samples of the sand fraction were mortar-ground and analyzed on glass slides (unoriented). The diffractometer PANalytical, 
model X 'PertPRO was used, under $\mathrm{CoK} \alpha$ radiation $(1.7889 \mathrm{~nm})$ to scan the sample in a range of 4 to $50^{\circ} 2 \theta$, at intervals of $0.02^{\circ} 2 \theta$ to 1 step per second, at a voltage of $40 \mathrm{kV}$ and current of $30 \mathrm{~mA}$.

Quartz was identified in the sand fraction of both soils (RYL-cl and RYL-sl). In the silt fraction of RYL-cl, kaolinite, gibbsite, goethite, and quartz were detected and in that of RYL-sl kaolinite and gibbsite and quartz. In the clay fraction of both soils (RYL-cl and RYL-sl) kaolinite, gibbsite and goethite were found.

Phosphorus sorption and desorption were assessed by the stirred flow technique (Figure 1), similar to the system described by Bar-Tal et al. (1990) and Strawn \& Sparks (2000). This technique has been used for many years in several countries in kinetic studies, but is little known in Brazil (Carski \& Sparks, 1985; Bar-Tal et al., 1990; Strawn \& Sparks, 2000; Staats et al., 2004; Pérez-Novo et al., 2011). The stirred-flow system consists of a tank with $\mathrm{N}$, receptors for stock solutions of $\mathrm{P}$ and citrate, a peristaltic pump with a flow rate of $1.58 \mathrm{~mL} \mathrm{~min}^{-1}$, a $12 \mathrm{~mL}$ reaction chamber, magnetic stirrer, two filters (diameter $25 \mathrm{~mm}$, pore size $0.45 \mu \mathrm{m}$ ) to separate the soil from the reaction solution, and tubes for sample collection. In the reaction chamber, a soil:solution ratio of 1:11 was used, as proposed by Bar-Tal et al. (1990), Strawn \& Sparks (2000) and Carski \& Sparks (1985).

As $\mathrm{P}$ source we used $\mathrm{KH}_{2} \mathrm{PO}_{4}$. The $\mathrm{P}$ and citrate solutions were prepared at a molar ratio of $1: 1(\mathrm{P}$ : citrate), and the $\mathrm{pH}$ was adjusted to 4.8 with $\mathrm{KOH}$ and ionic strength to $10 \mathrm{mmol} \mathrm{L}^{-1}$ with $\mathrm{KCl}$.

\section{Effect of $P$ citrate sorption}

The treatments were evaluated in a $2 \times 5$ factorial design with two soils (RYL-cl and RYL-sl), five combinations of $\mathrm{P}$ and citrate applications (only $\mathrm{P}, \mathrm{P}$ and citrate together and citrate applied 7, 22 and 52 min before $\mathrm{P}$ ). The experiment was arranged in a randomized block design with three replications. Phosphorus and citrate solutions were prepared at a concentration of $0.1290 \mathrm{mmol} \mathrm{L}^{-1}$ each.

For the control treatments ( $\mathrm{P}$ only) and $\mathrm{P}+$ citrate together $\left(\mathrm{CiP}_{j}\right), 1 \mathrm{~g}$ of soil was placed in the reaction chamber and the solution (containing a concentration

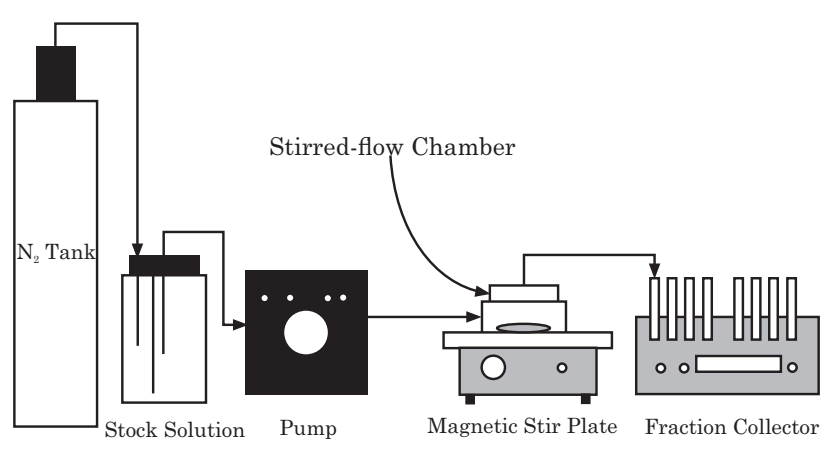

Figure 1. Stirred-flow system (Strawn \& Sparks, 2000). of $\mathrm{P}$ or $\mathrm{P}+$ citrate) was pumped into the chamber under agitation (Figure 1). The entire volume of the solutions leaving the chamber was collected after the beginning of the flow, after the first $2 \mathrm{~min}$ and then every 5 min until 62 min.

For treatments with citrate application prior to the addition of $\mathrm{P}\left(\mathrm{Ci}_{a} \mathrm{P}_{d}\right), 1 \mathrm{~g}$ of soil was placed in the reaction chamber and a citrate solution was pumped into the chamber under stirring (Figure 1). After 7 $\left(\mathrm{Ci}_{a} \mathrm{P}_{d} 7_{\text {min }}\right), 22\left(\mathrm{Ci}_{a} \mathrm{P}_{d} 22_{\text {min }}\right)$ and $52 \min \left(\mathrm{Ci}_{a} \mathrm{P}_{d} 52_{\text {min }}\right)$ of citrate addition, the flow was stopped and $\mathrm{P}$ application initiated. The entire volume of the solutions leaving the chamber was collected initially from 0 to $2 \mathrm{~min}$ and then every $5 \mathrm{~min}$, until $62 \mathrm{~min}$. The $\mathrm{P}$ concentration was determined by phosphomolybdic complex colorimetry (Braga \& Defelipo, 1974).

To estimate $\mathrm{P}$ retention by the chamber (control), the above procedure was carried out without the soil sample.

The amount of $\mathrm{P}$ in soil sorbed by the different treatments was calculated as the difference between the concentration in the solution leaving the system with and without soil, according to equation 2, proposed by Sparks et al. (1996) and Yin et al. (1997)

$$
q a(t i)=\frac{\Sigma\left(\frac{(C i b-C i s) j \Delta t i}{V}\right)}{W}
$$

where qa(ti): cumulative $P$ sorption at time $t$, in $\mathrm{mg} \mathrm{g}^{-1} ; \mathrm{J}$ : chamber input flow, in $\mathrm{L} \mathrm{min}^{-1} ; \Delta$ ti: time of sampling interval, in min; Cib: $\mathrm{P}$ concentration in the effluent during the sampling period, in $\mathrm{mg} \mathrm{L}^{-1}$, in the system without soil (control); Cis: P concentration in the effluent during the sampling period, in $\mathrm{m} \mathrm{L} \mathrm{L}^{-1}$, in the system with soil; V: volume of the reaction chamber in L; and W: soil concentration in the chamber, in $\mathrm{g} \mathrm{L}^{-1}$.

From the amount sorbed per sampling period, the cumulative sorbed $\mathrm{P}$ was computed from the sum of soil $\mathrm{P}$ sorption in the sampling period between 0 and $62 \mathrm{~min}$. After the analysis of variance of the cumulative sorbed $\mathrm{P}$ content, means were compared by the Tukey test $(\mathrm{p} \leq 0.05)$, using the statistical program Statistica 7.

\section{Effect of $P$ on citrate sorption}

The treatments were arranged in a $2 \times 2$ factorial design with two soils (RYL-cl and RYL-sl) and two solutions applied to the soil (only citrate or citrate + $\mathrm{P})$. The experiment was conducted in a randomized complete block design with three replications. The citrate and $\mathrm{P}$ solutions were both prepared at a concentration of $0.1290 \mathrm{mmol} \mathrm{L}^{-1}$.

In these treatments, $1 \mathrm{~g}$ of soil was placed in the reaction chamber and the solution containing a citrate or citrate $+\mathrm{P}$ concentration was pumped into the 
chamber under stirring (Figure 1). The entire volume of the solutions leaving the chamber was collected after the beginning of the flow, after the first $2 \mathrm{~min}$ and then every 5 min until $62 \mathrm{~min}$, as previously described. Citrate concentration was determined by high performance liquid chromatography (HPLC).

To estimate citrate retention in the chamber (control), the above procedure was carried out without addition of the soil sample.

The amount of citrate sorbed per treatment was calculated as described above for P sorption. From the amount sorbed during each interval, cumulative sorbed citrate was calculated as the sum of citrate in the soil sorbed in the period from 0 to $62 \mathrm{~min}$ of collection.

After the analysis of variance of the cumulative content of sorbed citrate, means were compared by the Tukey test $(\mathrm{p} \leq 0.05)$, using the statistical program Statistica 7.

\section{Incubation time and desorption of soil $\mathrm{P}$}

The treatments were arranged in a $2 \times 2 \times 6$ factorial design, testing two soils (RYL-cl and RYL-sl), two extractors (citrate $0.1290 \mathrm{mmol} \mathrm{L}^{-1}$ and water with ionic strength adjusted to $10 \mathrm{mmol} \mathrm{L}^{-1}$ $\mathrm{KCl})$ and six incubation periods of $\mathrm{P}(0,6,24,240$, 480 , and $960 \mathrm{~h}$ ). Time zero (0) corresponded to about $1 \mathrm{~min}$, the time required to close the chamber.

For the experiment, each treatment was incubated with soil with $50 \mathrm{~g}$ of $\mathrm{P}$ corresponding to $50 \%$ of the MPSC of each soil (RYL-cl $=0.545 \mathrm{mg} \mathrm{g}^{-1}$ and RYL-sl $\left.=0.200 \mathrm{mg} \mathrm{g}^{-1}\right), 80 \%$ of the field capacity, in a randomized block design.

After the incubation periods, $1 \mathrm{~g}$ of soil was placed in the reaction chamber; a solution with the citrate concentration or water was pumped into the chamber under stirring (Figure 1). The entire volume of the solutions leaving the chamber was collected after the beginning of the flow, after the first $2 \mathrm{~min}$ and then every 5 min until $62 \mathrm{~min}$, as described above. The $\mathrm{P}$ content was determined by phosphomolybdic complex colorimetry (Braga \& Defelipo, 1974).

To estimate $\mathrm{P}$ desorption in the chamber (control), the procedure described above was applied in the absence of soil.

The amount of $\mathrm{P}$ desorbed by the soil in the different treatments was calculated as the difference between the concentration in the solution leaving the system with and without soil, according to the equation proposed by Sparks et al. (1996) and Yin et al. (1997), as described above. From the sum of the desorbed amount at each time, the cumulative desorbed $\mathrm{P}$ was obtained, which corresponds to the sum of $\mathrm{P}$ in soil desorbed from 0 to 62 min of collection.

For the content of cumulative desorbed $\mathrm{P}$ after analysis of variance, regressions of desorbed $\mathrm{P}$ according to the incubation period were adjusted using the statistical program Statistica 7.

\section{RESULTS AND DISCUSSION}

\section{Effect of citrate on $P$ sorption}

Phosphorus sorption in the RYL-cl was 0.173 $\mathrm{mg} \mathrm{g}^{-1}$, which was higher than sorption in the RYLsl $\left(0.099 \mathrm{mg} \mathrm{g}^{-1}\right)$ (Table 2). These values obtained with the stirred flow technique corresponded to 16 and 25 $\%$ of MPSC of the RYL-cl (1.09 $\left.\mathrm{mg} \mathrm{g}^{-1}\right)$ and RYL-sl $\left(0.40 \mathrm{mg} \mathrm{g}^{-1}\right)$, respectively. The differences between the results obtained with the stirred flow technique and the standard method of MPSC determination are a consequence of the method characteristics. To determine MPSC, the soil was in contact for $24 \mathrm{~h}$ with increasing rates $\mathrm{P}$, of up to $200 \mathrm{mg} \mathrm{L}^{-1} \mathrm{P}$ to RYL-cl and $100 \mathrm{mg} \mathrm{L}^{-1} \mathrm{P}$ to RYL-sl. This contact time and application rates were higher than those used in the stirred-flow tests.

In both soils, $\mathrm{P}$ sorption was reduced when citrate was added, especially when higher amounts of citrate were applied for 22 and 52 min before $\mathrm{P}$ application, or when $\mathrm{P}$ and citrate were applied together (Table 2). During 62 min of $P$ application at a rate of $1.58 \mathrm{~mL} \mathrm{~min}^{-1}, 0.39 \mathrm{mg} \mathrm{g}^{-1} \mathrm{P}$ was applied to the soils. When no citrate was added, $\mathrm{P}$ sorption corresponded to 44.1 and $25.2 \%$ of $\mathrm{P}$ applied to the RYL-cl and RYL-sl, respectively (Table 2). With citrate application for 7 min before $\mathrm{P}$ application, $34.8 \%$ of $\mathrm{P}$ applied was sorbed to RYL-cl. In the RYL-sl, the P sorption with citrate application for $7 \mathrm{~min}$ before $\mathrm{P}$ was $21.4 \%$ of $\mathrm{P}$ applied to the soil. After citrate application for 22 min before $\mathrm{P}$ application, $\mathrm{P}$ sorption was $0.066 \mathrm{mg} \mathrm{g}^{-1}$ lower than that of the control in RYL-cl, reducing sorption to $27.6 \%$ of $\mathrm{P}$ applied to the soil. In RYL-sl, citrate application reduced $\mathrm{P}$ sorption by $0.049 \mathrm{mg} \mathrm{g}^{-1}$; in this treatment, P sorption was $12.7 \%$ of $\mathrm{P}$ applied to the soil. In the longest previous

Table 2. Mean cumulative concentrations, in the sampling period of 0 to $62 \mathrm{~min}$, of $\mathrm{P}$ sorbed to soil with clayey texture Oxisol (RYL-cl) and with sandy-loam texture Oxisol (RYL-sl)

\begin{tabular}{lllll}
\hline \multirow{2}{*}{ Treatment $^{(1)}$} & \multicolumn{4}{c}{ Sorbed $\mathbf{P}^{(2)}$} \\
\cline { 2 - 5 } & \multicolumn{5}{c}{ RYL-cl } & \multicolumn{3}{c}{ RYL-sl } \\
\cline { 2 - 5 } & $\mathrm{mg} \mathrm{g}^{-1}$ & $(\%)$ \\
$\mathrm{Control}$ & $0.173 \mathrm{Aa}$ & $(44.1)$ & $0.099 \mathrm{Ab}$ & $(25.2)$ \\
$\mathrm{Ci}_{\mathrm{a}} \mathrm{P}_{\mathrm{d}} 7_{\min }$ & $0.136 \mathrm{Ba}$ & $(34.8)$ & $0.084 \mathrm{ABb}$ & $(21.4)$ \\
$\mathrm{CiP}_{\mathrm{j}}$ & $0.101 \mathrm{Ca}$ & $(25.8)$ & $0.065 \mathrm{BCb}$ & $(16.7)$ \\
$\mathrm{Ci}_{\mathrm{a}} \mathrm{P}_{\mathrm{d}} 22_{\text {min }}$ & $0.107 \mathrm{Ca}$ & $(27.6)$ & $0.050 \mathrm{Cb}$ & $(12.7)$ \\
$\mathrm{Ci}_{\mathrm{a}} \mathrm{P}_{\mathrm{d}} 52_{\text {min }}$ & $0.105 \mathrm{Ca}$ & $(26.7)$ & $0.041 \mathrm{Cb}$ & $(10.4)$ \\
\hline
\end{tabular}

(1) Cumulative $\mathrm{P}$ sorption in the soil without citrate application (control), with $\mathrm{P}$ and citrate together $\left(\mathrm{CiP}_{\mathrm{j}}\right)$ and with citrate applied 7,22 and 52 min before $\mathrm{P}\left(\mathrm{Ci}_{\mathrm{a}} \mathrm{P}_{\mathrm{d}} 7_{\min }, \mathrm{Ci}_{\mathrm{a}} \mathrm{P}_{\mathrm{d}} 22_{\min }\right.$ $\mathrm{Ci}_{\mathrm{a}} \mathrm{P}_{\mathrm{d}} 52_{\text {min) }}$, after $62 \mathrm{~min}$ of reaction. ${ }^{(2)}$ In parentheses, percentage of $\mathrm{P}$ applied sorbed to soil. Means followed by the same capital letter in a column and lowercase letter in a row did not differ from each other by the Tukey test at $5 \%$. 
application period of citrate (52 min), $\mathrm{P}$ sorption was significantly reduced; RYL-cl sorbed $26.7 \%$ and RYL-sl $10.4 \%$ of $\mathrm{P}$ applied to the soil.

The application of $\mathrm{P}$ and citrate together reduced $\mathrm{P}$ sorption by 0.072 and $0.034 \mathrm{mg} \mathrm{g}^{-1}$ in the RYL-sl and RYL-cl soils, respectively (Table 2), corresponding to the sorption of $25.8 \%$ of $\mathrm{P}$ applied to RYL-cl and $16.7 \%$ to the RYL-sl. The effectiveness of organic acids in decreasing $\mathrm{P}$ sorption in soil has been reported elsewhere (Geelhoed et al., 1999; Johnson \& Loeppert, 2006; Moradi et al., 2012).

\section{Effect of $\mathbf{P}$ citrate sorption}

The evaluation period for citrate sorption was sufficient to record detectable changes. Strom et al. (2001) measured the sorption of organic acid for 60 min and observed that all citrate, malate and oxalate were sorbed to the soil in less than $5 \mathrm{~min}$.

Citrate sorption in the RYL-cl was higher than in RYL-sl (Table 3) and was directly proportional to the MPSC of each soil. Probably, most P sorption sites are similar to those of citrate, which may vary with soil characteristics such as texture, mineralogy and concentration of $\mathrm{Fe}$ and $\mathrm{Al}$ oxyhydroxides. Phosphorus application together with citrate significantly reduced citrate sorption in both soils (Table 3).

Throughout the $62 \mathrm{~min}, 2.42 \mathrm{mg} \mathrm{g}^{-1}$ citrate was applied to each soil. Citrate sorption was highest $(0.778$ $\mathrm{mg} \mathrm{g}^{-1}$ ) in RYL-cl without $\mathrm{P}$ application, corresponding to $32.0 \%$ of the citrate applied. In the same treatment in RYL-sl, the highest citrate sorption $\left(0.734 \mathrm{mg} \mathrm{g}^{-1}\right)$ was $30.2 \%$ of the citrate applied (Table 3 ). In the P application to RYL-cl, citrate was significantly reduced by $0.136 \mathrm{mg} \mathrm{g}^{-1}$ by citrate sorption; in this treatment, citrate sorption represented $26.4 \%$ of the citrate applied. In RYL-sl, P application also reduced citrate sorption significantly by $0.255 \mathrm{mg} \mathrm{g}^{-1}$, corresponding to $19.7 \%$ of citrate applied to the soil (Table 3 ). The reduced citrate sorption after $\mathrm{P}$ application was probably due to blocking or competition for soil sorption sites, as stated by Oburger et al. (2011b). According

Table 3. Cumulative concentrations, in the collection period of 0 to $62 \mathrm{~min}$, of citrate sorbed to soils with clayey texture Oxisol (RYL-cl) and sandyloam texture Oxisol (RYL-sl) in the absence and presence of $P$

\begin{tabular}{lcccc}
\hline \multirow{2}{*}{ Treatment } & \multicolumn{4}{c}{ Sorbed citrate $^{(1)}$} \\
\cline { 2 - 5 } & RYL-cl & \multicolumn{2}{c}{ RYL-sl } \\
\hline & \multicolumn{5}{c}{$\mathrm{mg} \mathrm{g}^{-1}$} & $(\%)$ \\
$-\mathrm{P}$ & $0.778 \mathrm{Aa}$ & $(32.0)$ & $0.734 \mathrm{Ab}$ & $(30.2)$ \\
$+\mathrm{P}$ & $0.641 \mathrm{Ba}$ & $(26.4)$ & $0.479 \mathrm{Bb}$ & $(19.7)$ \\
\hline
\end{tabular}

(1) In parentheses, percentage of citrate applied sorbed to the soil. Means followed by the same capital letter in a column and lowercase letter in a row did not differ from each other by the Tukey test at $5 \%$, after $62 \mathrm{~min}$ of reaction. to these authors, the higher the content of $\mathrm{P}, \mathrm{SOM}$ or sulfate, the lower is citrate sorption.

Under natural conditions, sorption of citrate exudated by plants can occur (Silva et al., 2001). The exudated citrate can be sorbed, decomposed or remain in solution for short time periods, competing directly with $\mathrm{P}$ for the soil sorption sites (Oburger et al., 2011b).

In general, all citrate application forms were effective in reducing $\mathrm{P}$ sorption. The reduction of $\mathrm{P}$ sorption by citrate may occur by previous blocking of the sites or by competition between sites. Citrate application can also influence mineral dissolution, mainly by removing $\mathrm{Fe}$ and $\mathrm{Al}$ from crystalline or poorly crystallized structures, increasing the competitive sorption between $\mathrm{P}$ and citrate and reducing the sorption surface of $\mathrm{P}$ of the mineral. Anions which remain in the soil can form complexes with cations that also reduce phosphate precipitation (Sposito, 1989). Citrate is sorbed to the soil similar to inorganic anions and its affinity to the surface of minerals is similar to $\mathrm{P}$ sorption (Pavinato \& Rosolem, 2008). The affinity of the anions for soil sorption sites follows the sequence: phosphate $>$ citrate $>$ malate $>$ acetate (van Hees et al., 2003; Guppy et al., 2005).

\section{Incubation time and soil $\mathbf{P}$ desorption}

Citrate application increased the desorption of $\mathrm{P}$ applied to soils (Figure 2). For both soils, P desorption in response to citrate application was higher than $\mathrm{P}$ desorption with water, in view of the competition of citrate with $\mathrm{P}$ for similar soil sorption sites, as already noted by other authors (Geelhoed et al., 1999; Johnson \& Loeppert, 2006; Moradi et al., 2012). Oburger et al. (2011a) observed a similar response in P desorption with citrate addition, causing a mean desorption of $13.0 \%$ of the P applied to the soil and only $3.0 \%$ of $\mathrm{P}$ was desorbed with water after an application of $24 \mathrm{mg} \mathrm{kg}^{-1} \mathrm{P}$.

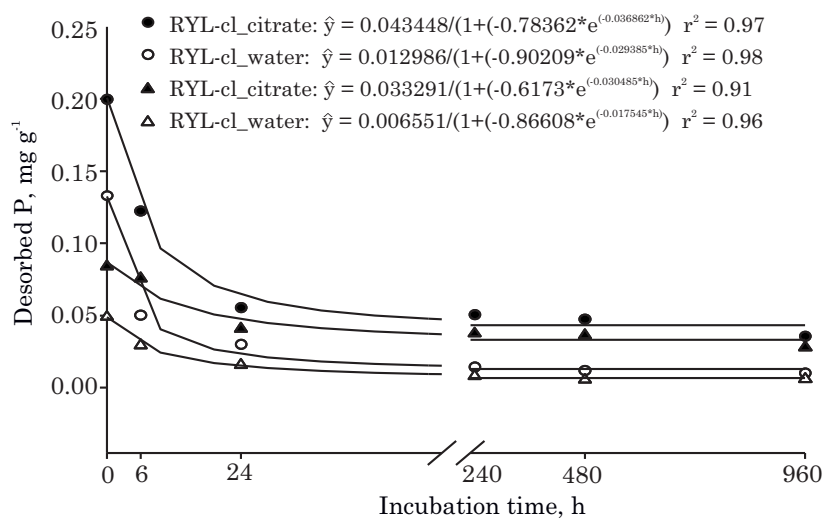

Figure 2. Concentration of desorbed $P$ during 62 min of reaction, in clayey (RYL-cl) and sandy-loam texture Oxisol (RYL-sl), with citrate and water, in incubation periods of $0,6,24,240,480$, and $960 \mathrm{~h}$. * significant at $1 \%$ by the $\mathrm{F}$ test. 
Phosphorus desorption by citrate can occur under natural conditions by root exudation or organic matter decomposition (Johnson \& Loeppert, 2006; Pavinato $\&$ Rosolem, 2008). More than $99 \%$ of the organic acid exudates remain within a distance of $1 \mathrm{~mm}$ from the root surface, increasing the chances of $\mathrm{P}$ desorption in this region (Jones et al. 1996).

During the period of $0-960 \mathrm{~h}$ of incubation (Figure 2 ), two regions of $\mathrm{P}$ desorption by citrate and water were observed in the RYL-cl and RYL-sl: one with greater $\mathrm{P}$ desorption, from 0 to about $24 \mathrm{~h}$ after $\mathrm{P}$ incubation and the other with lower $\mathrm{P}$ desorption after this incubation period.

Phosphorus sorption reactions are fast, and over time the bonds age in the soil (Novais \& Smyth, 1999). Phosphorus is initially retained by electrostatic attraction and simple coordinate bonds and, under this condition, the small portion of $\mathrm{P}$ in equilibrium with the soil solution is called labile $P$. This rapid sorption phase is followed by a slower phase consisting of the formation of an additional bond to the first between $\mathrm{P}$ and the absorbent surface, transforming labile $\mathrm{P}$ in desorption-resistant, non-labile $\mathrm{P}$ (Novais \& Smyth, 1999; Fernández et al., 2008). Measuring $\mathrm{P}$ sorption in $\mathrm{Fe}$ and $\mathrm{Al}$ oxyhydroxides, Harvey \& Rhue (2008) observed that 80 to $90 \%$ of $\mathrm{P}$ was sorbed in the first three hours of sorption of these minerals.

Soil $\mathrm{P}$ availability after manure (poultry, cattle and goat) application was evaluated after 120 days by Azeez \& Averbeke (2010). According to these authors, the $\mathrm{P}$ availability initially increases with organic matter mineralization, but 120 days after slurry application, more than $90 \%$ of the mineralized $\mathrm{P}$ was no longer available. Similarly, Santos et al. (2011) observed that the longer the soil-P contact time, the lower is the percentage of desorbed $\mathrm{P}$, regardless of the soil type or extractor (Table 4). In RYL-cl, P desorption with citrate was $36.7,22.4,10.3,9.4,8.6$, and $6.6 \%$ of $\mathrm{P}$ applied to the soil in incubation periods in soil for $0,6,24,240,480$, and $960 \mathrm{~h}$, respectively.

Table 4. Phosphorus desorbed during $62 \mathrm{~min}$ of each incubation period $(0,6,24,240,480,960 \mathrm{~h})$, in a clayey texture Oxisol (RYL-cl) and a sandy-loam texture Oxisol (RYL-sl)

\begin{tabular}{|c|c|c|c|c|}
\hline \multirow{2}{*}{ Incubation period } & \multicolumn{2}{|c|}{ RYL-cl } & \multicolumn{2}{|c|}{ RYL-sl } \\
\hline & Citrate & Water & Citrate & Water \\
\hline $\mathrm{h}$ & \multicolumn{4}{|c|}{$\%^{(1)}$} \\
\hline 0 & 36.7 & 24.4 & 42.0 & 24.5 \\
\hline 6 & 22.4 & 9.2 & 38.0 & 14.5 \\
\hline 24 & 10.3 & 5.5 & 20.5 & 8.0 \\
\hline 240 & 9.4 & 2.6 & 19.0 & 4.0 \\
\hline 480 & 8.6 & 2.2 & 18.0 & 2.5 \\
\hline 960 & 6.6 & 1.8 & 14.0 & 3.0 \\
\hline
\end{tabular}

(1) Percentage of $\mathrm{P}$ in relation to the applied rate, equivalent to $50 \%$ of the MPSC.
The values of water desorption were always below those of citrate, with $24.4,9.2,5.5,2.6 ; 2.2$; and $1.8 \%$ of $\mathrm{P}$ applied in the same incubation periods.

In RYL-sl, the percentage of $\mathrm{P}$ desorption was higher than in RYL-cl in all incubation periods considering desorption with citrate and water (Table 4). The higher percentage of desorption of $P$ applied to the RYL-sl was mainly due to its lower clay content and lower MPSC. According to Santos et al. (2011), P desorption is related to the properties of a soil, e.g., to clay mineralogy and content. According to Broggi et al. (2010), $\mathrm{P}$ sorption is higher in soils with predominantly gibbsite in the clay fraction. These authors reported two extreme values of $\mathrm{P}$ desorption in soil incubated for 90 days: $2 \%$ of $\mathrm{P}$ applied to an Oxisol and $51 \%$ to a Vertisol. In soils incubated with $\mathrm{P}$ up to 60 days, Kaloí et al. (2011) observed that the longer the incubation time, the lower was P recovery, inversely proportional to the content or clay weathering degree.

Duputel et al. (2013) used data modeling to assess the effects of citrate sorption on $\mathrm{P}$ availability and observed more effective competition of citrate in weathered soils, in the absence of $2: 1$ minerals and predominance of goethite. In Oxisols, they observed that the mineral with highest citrate sorption was goethite, leading to increased negative charges, especially at lower $\mathrm{pH}$. In this study, the average $\mathrm{pH}$ of the two Oxisols was 4.75.

The $\mathrm{P}$ sorption observed in this study reached more than $40 \%$ of the P applied in clayey Oxisol. The problem of $\mathrm{P}$ sorption in highly weathered soils is a widely known challenge, calling for strategies to mitigate this phenomenon. The effect of reducing $\mathrm{P}$ sorption with citrate application was tested with a stirred-flow system. The resulting data showed that the technique represents an alternative for tests involving $\mathrm{P}$ sorption and even includes the possibility of testing sorption followed by desorption, in the same study.

Thus, the results deepen the understanding of sorption and desorption processes and allow conclusions about management possibilities to increase $\mathrm{P}$ availability suggesting, for example, the selection of species that produce larger amounts of organic acids with higher amounts of carboxylic groups (ex. citric acid, which is tricarboxylic), or managements that increase organic residues and SOM.

\section{CONCLUSIONS}

1. Citrate decreases $P$ sorption in soils, while in turn phosphate is effective in reducing citrate sorption. The lower $\mathrm{P}$ sorption in the presence of citrate and the lower citrate sorption in the presence of $\mathrm{P}$ is the result of the occupation of sites with similar affinities for $\mathrm{P}$ and citrate. 
2. Phopshorus desorption with citrate is higher than with water, showing that $\mathrm{P}$ availability to plants is probably greater in soils with higher citrate concentrations.

3. In desorption of $\mathrm{P}$ to the soil as a function of incubation time, two regions were observed: an initial region of higher $\mathrm{P}$ desorption, followed by lower $\mathrm{P}$ desorption, resulting in less $\mathrm{P}$ available to plants with increasing soil - $\mathrm{P}$ contact time.

\section{LITERATURE CITED}

ALVAREZ V., V.H. \& FONSECA, D.M. Definição de doses de fósforo para determinação da capacidade máxima de adsorção de fosfatos e para ensaios em casa de vegetação. R. Bras. Ci. Solo, 14:49-55, 1990.

ALVAREZ V., V.H.; NOVAIS, R.F.; DIAS, L.E \& OLIVEIRA, J.A. Determinação e uso do fósforo remanescente. Bol. Inf. Soc. Bras. Ci. Solo, 25:27-32, 2000.

ANDRADE, F.V.; MENDONÇA, E.S.; ALVAREZ V., V.H. \& NOVAIS, R.F. Adição de ácidos orgânicos e húmicos em Latossolos e adsorção de fosfato. R. Bras. Ci. Solo, 27:10031011, 2003.

AZEEZ, J.O. \& AVERBEKE, V.W. Fate of manure phosphorus in a weathered sandy clay loam soil amended with three animal manures. Bioresour. Technol., 101:6584-6588, 2010.

BAR-TAL, A.; SPARKS, D.L.; PESEK, J.D. \& FEIGENBAUM, S. Analyses of adsorption kinetics using a stirred-flow chamber: I. Theory and critical tests. Soil Sci. Soc. Am. J., 54:1273-1278, 1990.

BRAGA, J.M. \& DEFELIPO, B.V. Determinação espectrofotométrica de fósforo em extratos de solo e material vegetal. R. Ceres, 21:73-85, 1974.

BROGGI, F.; OLIVEIRA, A.C.; FREIRE, F.J.; FREIRE, M.B.G.S \& NASCIMENTO, C.W.A. Adsorption and chemical extraction of phosphorus as a function of soil incubation time. R. Bras. Eng. Agric. Amb., 14: 32-38, 2010.

CARSKI, T.H. \& SPARKS, D.L. A modified miscible displacement technique for investigating adsorptiondesorption kinetics in soils. Soil Sci. Soc. Am. J., 49:11141116, 1985.

DEFELIPO, B.V \& RIBEIRO, A.C. Análise química do solo metodologia. 2.ed. Viçosa, Universidade Federal de Viçosa, 1981. 17p. (Boletim de Extensão, 29)

DUPUTEL, A.M.; HOYEA, F.V.; TOUCETC, J. \& GERARD, F. Citrate adsorption can decrease soluble phosphate concentration in soil: Experimental and modeling evidence. Appl. Geochem., 39:15-23, 2013.

FEKRI, M.; GORGIN, N. \& SADEGH, L. Phosphorus desorption kinetics in two calcareous soils amended with $\mathrm{P}$ fertilizer and organic matter. Environ. Earth Sci., 64:721-729, 2011.
FERNÁNDEZ, I.E.R.; NOVAIS, R.F.; NUNES, F.N. \& KER, J.C. Reversibilidade de fósforo não-lábil em solos submetidos à redução microbiana e química. 11 - Extrações sucessivas do fósforo pela resina de troca aniônica. R. Bras. Ci. Solo, 32: 2319-2330, 2008.

GEELHOED, J.S.; VAN RIEMSDIJK,W.H. \& FINDENEGG, G.R. Simulation of the effect of citrate exudation from roots on the plant availability of phosphate adsorbed on goethite. Eur. J. Soil Sci., 50:379-390, 1999.

GONÇALVES, J.L.M.; FIRME, D.J.; NOVAIS, R.F \& RIBEIRO, A.C. Cinética de adsorção de fósforo em solos de cerrado. R. Bras. Ci. Solo, 9:107-111, 1985.

GUPPY, C.N.; MENZIES, N.W.; MOODY, P.W. \& BLAMEY, F.P.C. Competitive sorption reactions between phosphorus and organic matter in soil: A review. Aust. J. Soil Res., 43:189-202, 2005.

HAMDI, W.; PELSTER, D \& SEFFEN, M. Phosphorus sorption kinetics in different types of alkaline soils. Arch. Agron. Soil Sci., 60:577-586, 2014.

HARVEY, O.R. \& RHUE, R.D. Kinetics and energetics of phosphate sorption in a multi-component $\mathrm{Al}(\mathrm{III})$ - $\mathrm{Fe}$ (III) hydr(oxide) sorbent system. J. Colloid Interf. Sci., 322:384$393,2008$.

HAYNES, R.J. Lime and phosphate in the soil-plant system. Adv. Agron., 37:249-315, 1984.

JOHNSON, S.E. \& LOEPPERT, R.H. Role of organic acids in phosphate mobilization from iron oxide. Soil Sci. Soc. Am. J., 70:222-234, 2006.

JONES, D.L.; DARRAH, P.R \& KOCHIAN, L.V. Critical evaluation of organic acid mediated iron dissolution in the rhizosphere and its potential role in root iron uptake. Plant Soil, 180:57-66, 1996.

KALOÍ, G.M.; BHUGHIO, N.; PANHWAR, R.N.; JUNEJO, S.; MARI, A.H \& BHUTTO, M.A. Influence of incubation period on phosphate release in two soils of district Hyderabad. J. Anim. Plant Sci., 21:665-670, 2011.

MORADI, N.; SADAGHIANI, M.; SEPEHR, E. \& MANDOULAKANI, B. Effects of low-molecular-weight organic acids on phosphorus sorption characteristics in some calcareous soils. Turk J. Agric. For., 36:459-468, 2012.

NAFIU, A. Effects of soil properties on the kinetics of desorption of phosphate from Alfisols by anion-exchange resins. J. Plant Nutr. Soil Sci., 172:101-107, 2009.

NOVAIS, R.F. \& SMYTH, T.J. Fósforo em solo e planta em condições tropicais. Viçosa, UFV, 1999. 399p.

OBURGER, E.; JONES, D.L \& WENZEL, W.W. Phosphorus saturation and $\mathrm{pH}$ differentially regulate the efficiency of organic acid anion-mediated $\mathrm{P}$ solubilization mechanisms in soil. Plant Soil, 341:363-382, 2011a.

OBURGER, E.; LEITNE, R.D.; JONES, D.L.; ZYGALAKIS, K.C.; SCHNEPF, A. \& ROOSE, T. Adsorption and desorption dynamics of citric acid anions in soil. Eur. J. Soil. Sci., 62:733-742, 2011b. 
OLSEN, S.R. \& WATANABE, F.S.A. Method to determine a phosphorus adsorption maximum of soil as measured by the Langmuir isotherm. Soil Sci. Soc. Am. Proc., 21:147$149,1957$.

PAVINATO, P.S. \& ROSOLEM, C.A. Disponibilidade de nutrientes no solo - decomposição e liberação de compostos orgânicos de resíduos vegetais. R. Bras. Ci. Solo, 32:911$920,2008$.

PÉREZ-NOVO, C.; FERNÁNDEZ-CALVINO, D.; BERMÚDEZCOUSO, A.; LÓPEZ-PERIAGO, J.E. \& ARIAS-ESTÉVEZ, $\mathrm{M}$. Influence of phosphorus on $\mathrm{Cu}$ sorption kinetics: Stirred flow chamber experiments. J. Hazard. Mater., 185:220-226, 2011.

RUIZ, H.A. Incremento da exatidão da análise granulométrica do solo por meio da coleta da suspensão (silte + argila). R. Bras. Ci. Solo, 29: 297-300, 2005.

SANTOS, H.C.; OLIVEIRA, F.H.T.; SALCEDO, I.H.; SOUZA, A.P. \& SILVA, V.D.M. Cinética de sorção de fósforo em solos do Estado da Paraíba. R. Bras. Ci. Solo, 35:1301-131, 2011.

SHARIATMADARI, H.; SHIRVANI, M \& JAFARI, A. Phosphorus release kinetics and availability in calcareous soils of selected arid and semiarid toposequences. Geoderma, 132:261-272, 2006.

SHARPLEY, A.N. Effect of soil properties on the kinetics of phosphorus desorption. Soil Sci. Soc. Am. J., 47:462-467, 1983.

SILVA, F.A.M.; NOGUEIRA, F.D.; RIBEIRO, L.L.; GODINHO, A. \& GUIMARÃES, P.T.G. Exsudação de ácidos orgânicos em rizosfera de plantas daninhas. Planta Daninha, 19:193196, 2001.

SOUZA, R.F.; FAQUIN, V.; TORRES, P.R.F. \& BALIZA, D.P. Calagem e adubação orgânica: influência na adsorção de fósforo em solos. R. Bras. Ci. Solo, 30: 975-983, 2006.
SPARKS, D.L.; TONER, C.V. \& CARSKI, T.H. Kinetic methods and measurements. In: SPARKS, D. L., ed. Methods of soil analysis: Chemical methods. SSSA, Madison, 1996. p.1275-1307.

SPOSITO, G. The chemistry of soils. New York, Oxford University, 1989. $277 \mathrm{p}$.

STAATS, K.E.; ARAI, Y. \& SPARKS, D.L. Alum amendment effects on phosphorus release and distribution in poultry litter-amended sandy soils. J. Environ. Qual., 33:19041911, 2004.

STRAWN, D.G. \& SPARKS, D.L. Effects of soil organic matter on the kinetics and mechanisms of $\mathrm{Pb}$ sorption and desorption in soil. Soil Sci. Soc. Am. J., 64:144-156, 2000.

STROM, L.; OWEN, A.G.; GODBOLD, D.L. \& JONES, D.L. Organic acid behavior in a calcareous soil: sorption reactions and biodegradation rates. Soil Biol. Biochem., 33:2125-2133, 2001.

VAN HEES, P.A.W.; VINOGRADOFF, S.I.; EDWARDS, A.C.; GODBOLD, D.L \& JONES, D.L. Low molecular weight organic acid adsorption in forest soils: effects on soil solution concentrations and biodegradation rates. Soil Biol. Biochem., 35:1015-1026, 2003.

WANG, X.; LIU, F.; TAN, W.; LI, W.; FENG, X. \& SPARKS, D. L. Characteristics of phosphate adsorption-desorption onto Ferrihydrite: Comparison with well-crystalline $\mathrm{Fe}$ (Hydr)oxides. Soil Sci., 178:1-11, 2013.

YEOMANS, J.C. \& BREMNER, J.M. A rapid and precise method for routine determination of organic carbon in soil. Commun. Soil Sci. Plant Anal., 19:1467-1476, 1988.

YIN, Y.; ALLEN, H.E.; HUANG, C.P.; SPARKS, D.L. \& SANDERS, P.F. Kinetics of mercury(II) adsorption and desorption on soil. Environ. Sci. Technol., 31:496-503, 1997. 